Plaw and Soll 99, 255-266 (1987).

c 1987 Martinus Nithoff Publishers. Dordrecht. Printed in the Netherlands.

Ms. 6701

\title{
Nodulation, nitrogen fixation and nitrogen uptake in pigeonpea (Cajanus cajan (L.) Millsp) of different maturity groups ${ }^{\star}$
}

\author{
J.V.D.K. KUMAR RAO and P.J. DART"* \\ International Crops Research Institute for the Semi-Arid Tropics (ICRISAT . Patancheru P.O. \\ A.P. 502324 . India
}

Received 3 January 1986. Revised August 1986

Key words Cajanus cajan Muturity groups Nitrogenase activity Nitrogen fixation Nitrogen uptake Nodulation

\begin{abstract}
Summary The seasonal patterns of nodulation, acetylene reduction, nitrogen uptake and nitrogen fixation were studied for 11 pigeonpea cultivars belonging to different maturity groups grown on an Alfisol at ICRISAT Center. Patancheru, India. In all cultivars the nodule number and mass increased to a maximum around 6080 days after sowing and then declined. The nodule number and mass of medium-and late-maturing cultivars was greater than that of early-maturing cultivars. The nitrogenase activity' per plant increased to 60 days after sowing and declined thereafter, with little activity at 100) days when the crop was fowering. At later stages of plant growth nodules formed down to $90 \mathrm{~cm}$ below the soil surface but those at greater depth appeared less active than those near the surface.

All the 11 cultivars continued to accumulate dry matter until 140 days, with most biomass production by the late-maturing cultivars (up to $11 \mathrm{tha}$ ') and least by the carly-maturing determinate cultivars $(4 \mathrm{tha}$ '). Total nitrogen uptake ranged from 69 to $1,34 \mathrm{~kg}$ ha '. Nitrogen fixation by pigeonpea was estimated as the diflerence in total nitrogen uptake between pigeonpea and sorghum and could amount to $69 \mathrm{~kg} \mathrm{~N}$ ha ' per season. or half the total nitrogen uptake. Fixation by pigeonpea increased with crop duration, but there were differences within each maturity group. The limitations of the methods used for estimating $N_{2}$, fixation by pigeonpea are discussed
\end{abstract}

\section{Introduction}

Pigeonpea is an important grain legume of the semi-arid tropics, with about 90 per cent of the total world production in India ${ }^{8}$ where it is generally grown as an annual crop, though it is intrinsically perennial'. A wide range of maturity groups exists in pigeonpea, an important factor in the adaptation of the crop to diverse agroclimatic areas and agronomic systems. Based on days to $50 \%$ flowering at ICRISAT, Patancheru, India, ten maturity groups ranging from 60 days to more than 160 days have been identified ${ }^{3}$. The crop is usually sown at the onset of the monsoon in June or July. In peninsular India, the early-maturing cultivars are harvested after 4-5 months, medium-maturing cultivars after

\footnotetext{
- Submitted as J.A. No. 552 by the International Crops Research Institute for the Semi-Arid Tropics (ICRISAT).

* Research School of Biological Sciences, Australian National University, Canberra City, P.O. Box. 475, ACT 2601, Australia.
} 
Table 1. Plant habit, maturity group and days to flowering of the pigeonpea cultivars used for experimentation

\begin{tabular}{lllr}
\hline Cultivar & Plant habit & $\begin{array}{l}\text { Days to } 50^{\circ} \\
\text { flowering }\end{array}$ & Maturity group \\
\hline Pant A-3 & D & 60 & 0 \\
Prabhat & D & $61-70$ & I \\
UPAS 120 & 1 & $71-80$ & II \\
T 21 & 1 & $81-90$ & III \\
BDN I & 1 & $101-110$ & V \\
No.14k & 1 & $101-110$ & V \\
Bhedaghat & 1 & $131-140$ & VII \\
JA 275 & 1 & $141-160$ & VIII \\
Bhandra & 1 & $141-160$ & VIII \\
T 7 & 1 & $141-160$ & VIII \\
NP(WR) 15 & I & Above 160 & IX \\
\hline
\end{tabular}

D - Determinate, 1 - Indeterminate.

see ICRISAT, 1978

5-6 months and late-maturing cultivars after 6-9 months. The first 3-4 months of growth takes place during the monsoon, and subsequent growth is mainly dependent on moisture stored in the soil.

It is particularly important to know the ability of pigeonpeas to nodulate and fix nitrogen as they are generally grown on marginal soils with little input. Although Kumar Rao and Dart ${ }^{4}$ discussed the biology of nodulation of a medium-maturing pigeonpea cultivar, little information is available on the comparative nodulation and nitrogen-fixing ability of cultivars from different maturity groups. We have therefore studied the seasonal pattern of nodulation, nitrogen fixation, and nitrogen uptake of 11 pigeonpea cultivars of different maturity groups.

\section{Materials and methods}

The experiment was conducted at ICRISAT Center, Patancheru, India, on an Alfisol (fine loamy, Udic Rhodustalfs) fertilized with single superphosphate at a rate of $17 \mathrm{~kg} \mathrm{Pha}^{-1}$. No nitrogenous fertilizer was applied. At sowing, the pigeonpea seed was inoculated with an effective rhizobium strain, IHP /14. The trial was sown on 8 July 1977. The pigeonpes cultivars used were selected from those most commonly grown by farmers and plant breeders in India (Table 1). The cultivars are grouped into three major maturity groups as follows: early (maturity groups 0 to III), medium (group V) and late (groups VIl to IX). A long-duration and photosensitive sorghum, cv IS 11758, that matures in about eight months at Hyderabad. was grown as one of the treatments to serve as an indicator of soil $\mathbf{N}$ available for plant growth, providing a non-fixing control for estimating $\mathrm{N}_{2}$ fixed by different cultivars of pigeonpea.

The experimental design was a randomized complete block with three replicates. Each plot measured $10 \mathrm{~m} \times 6 \mathrm{~m}$, with eight rows $75 \mathrm{~cm}$ apart. For pigeonpea, two seeds were sown per hill that were $20 \mathrm{~cm}$ apart; sorghum seeds were sown at a spacing of $10 \mathrm{~cm}$. The seedlings were thinned to one per hill. The plots were weeded by hand as and when required. Insect pests of aerial plant parts, particularly Heliothis armigera, were controlled by spraying the crop with endosulfan at $0.7 \mathrm{~kg} \mathrm{a.i.} \mathrm{ha-1.} \mathrm{The} \mathrm{crop} \mathrm{was} \mathrm{grown} \mathrm{under} \mathrm{rainfed} \mathrm{conditions} \mathrm{and} \mathrm{the} \mathrm{monthly} \mathrm{rainfall} \mathrm{and} \mathrm{mean}$ maximum and minimum temperatures during the growing period are given in Table 2. 


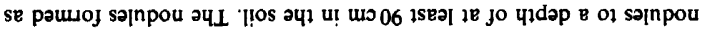

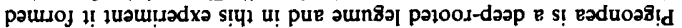

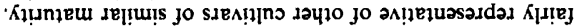

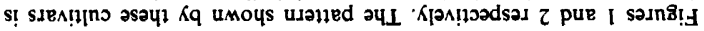
u! poluəsasd ase sdnos

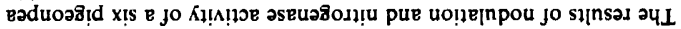

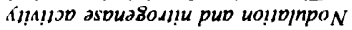

s]|nsay

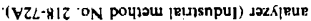
-oln

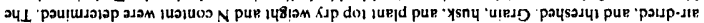

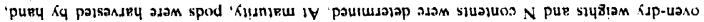

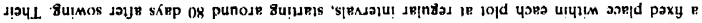

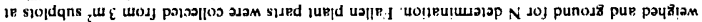

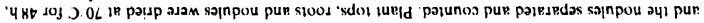

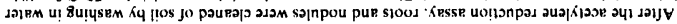

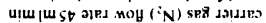

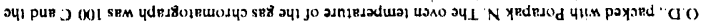

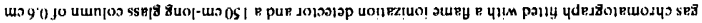

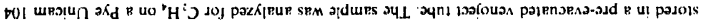

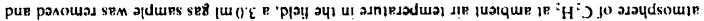

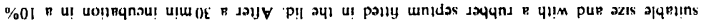

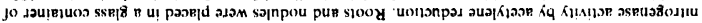

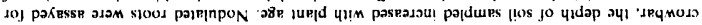

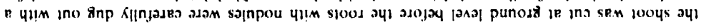

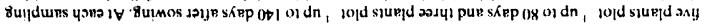

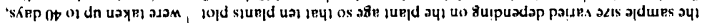

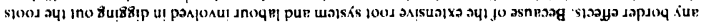

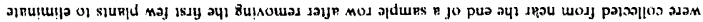

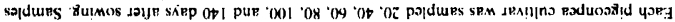

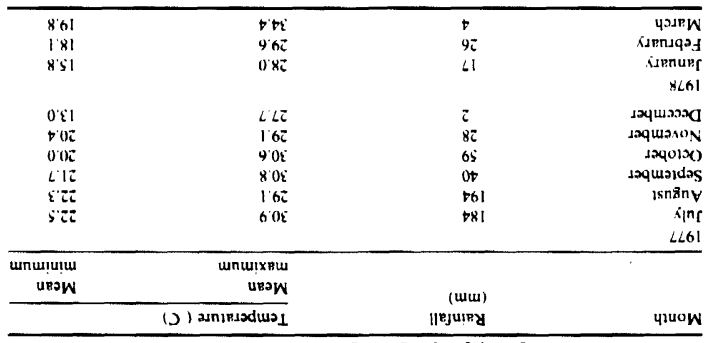

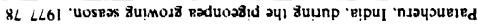

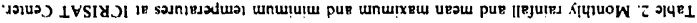



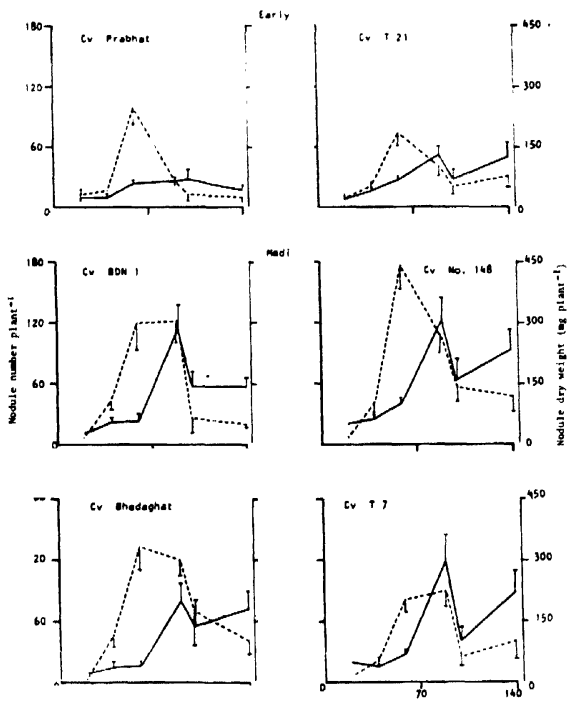

Fig. 1. Nodule number ( ) and dry weight $(\ldots .$.$) over time of pigeonpea cultivars of different$ maturities. Bars indicate standard error of mean.

early as $\mathbf{2 0}$ days after sowing were mostly on the primary root. These early-formed nodules senesced rapidly and nodules formed after 20 days were mostly found on secondary roots. In all the cultivars tested, nodule number and nodule mass increased with plant age and reached a maximum around 60-80 days after sowing, and declined thereafter (Figure 1). The nodulating ability of medium- and late-maturing pigeonpea cultivars was greater than that of early-maturing cultivars. Though the nodule number continued to increase up to 80 days after sowing, nodule weight did not show a corresponding increase. This was mainly because the nodules were destroyed by the larvae of the insect Rivellia angulata ${ }^{7}$.

In Figure 2, active $\mathrm{N}_{2}$ fixation was measurable by ARA within 20 days after sowing in all cultivars. The nitrogenase activity per plant increased 

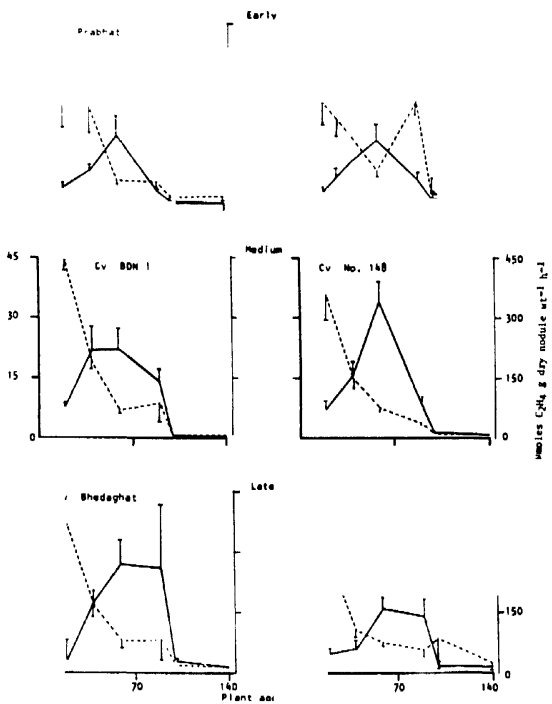

Fig. 2. Nitrogenase activity plant ' (-) and $g$ dry weight nodule ', , hour ${ }^{-1}$ over time of pigeonpea cultivars of different maturities. Bars indicate standard error of mean.

with plant age to a maximum at about 60 days after sowing. Thereafter activity declined and was minimal by 100 days, coinciding with the beginning of the postrainy season and the drying of the soil. The pattern of nitrogenase activity over the season in cultivars of different maturity groups closely followed that of nodule weight. The specific nitrogenase activity $\left(\mu M \mathrm{C}_{2} \mathrm{H}_{4} \mathrm{~g}\right.$ nodule dry $\left.\mathrm{wt}^{-1} \mathrm{~h}^{-1}\right)$ was greatest 20 days after sowing and then declined with time (Figure 2). A similar trend was seen in all cultivars and maturity groups except in cv $\mathrm{T} 21$ when a rise in specific nitrogenase activity was observed at 80 days after sowing. The reasons for this are not known. The deep-rooted nature of pigeonpea enables the crop to explore a large volume of soil for moisture and nutrients, particularly in the postrainy season when the medium- and 
late-maturing cultivars flower and mature. The nodules formed at deeper layers might not be so active as the nodules formed at a shallow depth $(0-30 \mathrm{~cm})$. At the $80-, 100-$, and 140-day harvests the color of cut nodule tissue of nodules from below $50 \mathrm{~cm}$ in the soil was usually white or brown, compared with a pink color for active nodules in the surface layers of soil. The decline in nitrogenase activity after 60 days could be due to several factors. Firstly, increased insect damage of nodules could have reduced the amount of active nodule tissue. Secondly, the recovery of nodules that were formed deep in the soil particularly in later harvests was probably incomplete. Thirdly, the cessation of nitrogenase activity after 100 days may well result from soil moisture deficit, even though the plants were apparently not stressed. Modelling studies suggest that for soybean the reduction in nitrogenase activity during pod fill is related to the decline in soil water below $50 \%$ of the plant available soil water holding capacity (T.R. Sinclair. Personal communication).

\section{Dry matter production}

Accumulation of dry matter in shoots and roots up to 140 days after sowing in pigeonpea plants of different maturity groups is presented in Figure 3. It increased similarly for the different cultivars. Final dry matter accumulated by cultivars increased with their maturity, but not grain yields which were as follows: early, $1.0-1.3 \mathrm{tha}^{-1}$; medium. $1.3-1.4$ tha '; late, $0.7-1.0 \mathrm{tha}^{-1}$. There was a wide range in harvest index, from 7 to $28 \%$ tending to decrease as plant biomass production and duration increased (Table 3 ). The cultivars also differed in the quantity of plant parts shed during the life cycle. It ranged from $0.5-1.0$ tha 'in early-maturing cultivars, from $1.3-1.6 \mathrm{t} \mathrm{ha}^{-1}$ in mediummaturing cultivars and from $1.2-1.9 \mathrm{tha}^{-1}$ in late-maturing cultivars.

\section{Nitrogen uptake and fixation}

The changes in nitrogen concentration with growth up to 140 days after sowing in plant tops, roots and nodules of pigeonpea cultivars of different maturity groups are presented in Figure 4 . As expected, young plants had the highest nitrogen concentration. The decline in nodule tissue nitrogen concentration paralleled that for nitrogenase activity per plant, with both measurements being at a maximum around 60 days after sowing. Though new nodule formation continued beyond 60 days after sowing. the presence of senescent tissue in the older nodules reduced the overall nodule nitrogen content. In plant tops, the nitrogen concentration declined after 40 days after sowing. The root nitrogen content declined rapidly after 20 days, but was quite stable after 60 days.

In the present study we attempted to estimate available soil nitrogen 


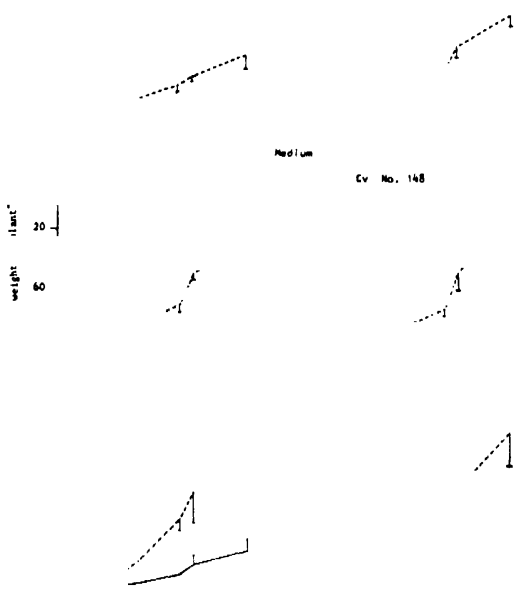

Fig. 3. Dry matter produced in shoot (--) and root without nodules (-) by pigeonpea cultivars of different maturities. Bars indicate standard error of mean.

by growing a long-duration sorghum cultivar. If we make the assumption that the roots of sorghum explore a similar volume of soil to that explored by pigeonpea over both time and space, and that both species take up all available soil nitrogen, then nitrogen fixation by the legume can be calculated as total legume nitrogen uptake minus total nonlegume nitrogen uptake. Tables 3 and 4 show the results of dry matter produced and total nitrogen uptake by pigeonpea and sorghum and estimates of $\mathrm{N}$ fixed by the 11 pigeonpea cultivars.

Total nitrogen uptake and net nitrogen fixation by pigeonpea generally increased with crop duration, but there were substantial differences between cultivars within a maturity group. Early-maturing determinate cultivars apparently fixed little nitrogen (maximum $7 \mathrm{~kg} \mathrm{~N}^{-1}$ ). Indeterminate early- and medium-maturing cultivars fixed more nitrogen, 
Table 3. Grain, dry matter production ( $\mathrm{kg}$ ha ' ') and harvest index at maturity of some pigeonpea cultivars and sorghum grown on an Alfisol at ICRISAT Center. Patancheru. India, 1977-78.

\begin{tabular}{|c|c|c|c|c|c|c|c|c|c|}
\hline Cultıvar & $\begin{array}{l}\text { Harvest } \\
\text { time } \\
\text { (days) }\end{array}$ & Grain & $\begin{array}{l}\text { Pod } \\
\text { wall }\end{array}$ & $\begin{array}{l}\text { Plant } \\
\text { top }\end{array}$ & Roots & Nodules & $\begin{array}{l}\text { Fallen } \\
\text { plant } \\
\text { parts }\end{array}$ & $\begin{array}{l}\text { Total } \\
\text { dry } \\
\text { matter }\end{array}$ & $\begin{array}{l}\text { Harvest } \\
\text { index } \\
(\%)\end{array}$ \\
\hline Pant A-3 & 140 & 1050 & 560 & 1390 & 440 & 0.8 & 540 & 3980 & 26 \\
\hline Prabhat & 140 & 1140 & 330 & 1560 & 330 & 2.0 & 680 & 4050 & 28 \\
\hline UPAS 120 & 140 & 1270 & 270 & 2120 & 710 & 1.9 & 900 & 5270 & 24 \\
\hline T 21 & 140 & 1350 & 740 & 2460 & 620 & 3.5 & 1060 & 6240 & 22 \\
\hline BDN 1 & 14() & 1300 & 660 & 26,30 & 480 & 3.8 & 1570 & 6640 & 20 \\
\hline$N_{0}, 148$ & 150 & 1370 & 550 & 3290 & 990 & 7.1 & 1260 & 7480 & 18 \\
\hline Bhedaghat & 172 & 720 & 670 & 3440 & 1590 & 4.6 & 1310 & 7730 & 9 \\
\hline JA 275 & 172 & 830 & 460 & 2470 & 1160 & 1.8 & 1160 & 6082 & 14 \\
\hline Bhandra & 230 & 1040 & 880 & 31160 & 1010 & 4.3 & 1910 & 7940 & 13 \\
\hline T 7 & 220 & 780 & 530 & 6240 & 2010 & 6.8 & 1370 & 10940 & 7 \\
\hline$N P(W R)$ is & 241 & 700 & 760 & 5210 & 1280 & 5.4 & 1200 & 9150 & 8 \\
\hline Sorghum & 175 & 150 & 560 & 8280 & 470 & & 0 & 9460 & \\
\hline SE & & \pm 118 & $\pm 1 \cdot 15$ & \pm 371 & \pm 241 & \pm 1.23 & \pm 149 & $\pm \$ 34$ & \\
\hline
\end{tabular}

the amount increasing with days to $50 \%$ flowering rather than to final harvest date ( 140 days). These cultivars ranged from 27 to $55 \mathrm{~kg} \mathrm{~N} \mathrm{ha}^{-1}$ based on the most conservative estimate. In late-maturing pigeonpea cultivars, the estimate of nitrogen fixed ranged from 13 to $69 \mathrm{~kg} \mathrm{~N} \mathrm{ha}{ }^{-1}$. Even for the best-fixing cultivar, T 7. $\mathrm{N}_{2}$ fixation represented only $52 \%$ of the total nitrogen uptake. The harvest index for nitrogen. that is the amount of $\mathrm{N}$ in the grain as a proportion of total plant nitrogen uptake was also small, ranging from $21 \%$ to $57 \%$ (mean of $38 \%$ ) and decreased with crop duration; this was about double the harvest index for dry matter (range 7 to $28 \%$, mean $17 \%$ ).

The amount of nodule tissue at the end of the season is very low and accounts for less than $0.2 \mathrm{~kg} \mathrm{~N}$ ha '. However, this is an underestimate of the total amount of nitrogen returned to the soil as nodules senesce, since this is a continual process starting about 30 days after sowing. Even so, such nodules contain on an average only $3.7 \% \mathrm{~N}$, much less than that found in active nodules (about $5.5 \% \mathrm{~N}$ ). Maximum nodule weight per plant was $300 \mathrm{mg}$ for $\mathrm{T} 7$ with a nitrogen content of $15 \mathrm{mg}$, extrapolating to $1.0 \mathrm{~kg} \mathrm{~N}$ ha ${ }^{1}$. This is still an underestimate of the return of $\mathrm{N}$ to the soil via nodule decay.

\section{Discussion}

The nitrogenase activity profiles differed relatively little between genotypes despite the large differences in net nitrogen fixation estimated by the difference method. Seasonal estimates of nitrogen fixation, derived by integrating the area under the curves for acetylene reduction 

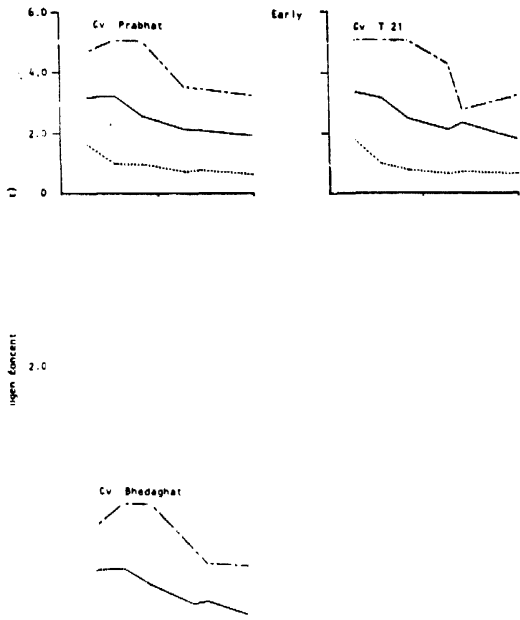

Fig. 4. Nitrogen concentration in tops ( - .), roots (. ) and nodules $(\cdot$. ) of pigeonpea cultivars of different maturities.

activity per plant over the season (Figure 2), and multiplying this by the plant population. using a conversion factor of 3 ( 1 mole of $\mathrm{N}_{2}$ fixed for 3 moles of $\mathrm{C}_{2} \mathrm{H}_{2}$ reduced to $\mathrm{C}_{2} \mathrm{H}_{4}$ ) were much lower than that estimated by the difference method (3-5 kg N ha ${ }^{\prime}$ ef $43-13 \mathrm{~kg} \mathrm{~N} \mathrm{ha}^{-1}$ for cultivars T 21 and JA $275^{\circ}$ ). This may be partly due to a large variation in the conversion factor during the life cycle. The attachment of pigeonpea nodules to the root system is also very fragile, and invariably nodules become detached from the roots during preparation for the assay. In other species such as soybean, nitrogenase activity is much reduced in detached nodules compared with nodules still attached to the root ( $\mathrm{J}$ Witty, personal communication).

It is difficult to measure net nitrogen fixation by pigeonpea grown in the field. because of the problem of estimating nitrate uptake by such a 


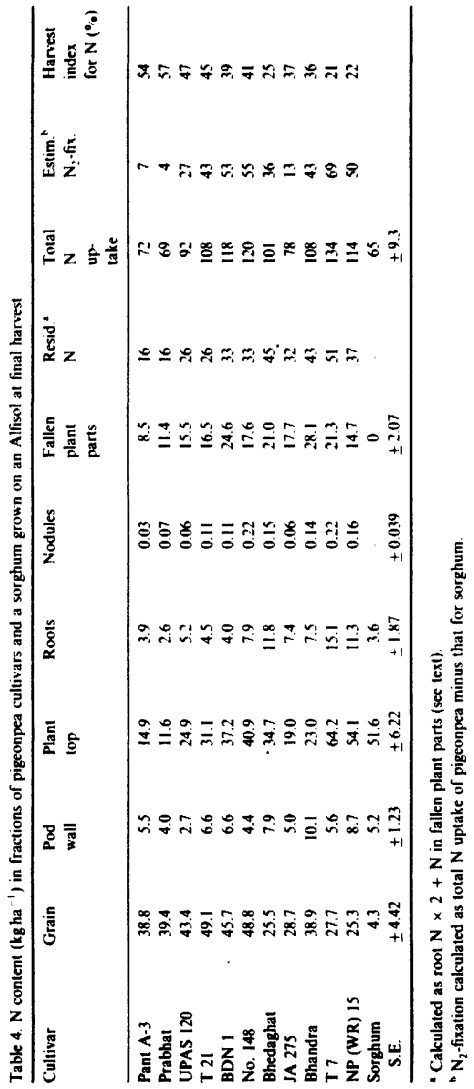


long-duration and deep-rooted crop. In the present study a long-duration sorghum was grown and harvested only once, 175 days after sowing. to measure available soil nitrogen. Thus the value of the nitrogen fixed by pigeonpea cultivars of early maturity (particularly Pant A-3 and Prabhat) is likely to be an underestimate. In addition the sorghum may have gained a small amount (up to $15 \mathrm{~kg} \mathrm{ha}^{-1}$ ) of nitrogen from nitrogen fixation by bacteria associated with its roots ${ }^{2}$, resulting in an underestimate for all values for pigeonpea nitrogen fixation.

Nitrogen fixation by pigeonpea generally increased with crop duration, but there were substantial differences between cultivars within a maturity group. Nevertheless, the present results suggest that the earlymaturing cultivars Pant A-3 and Prabhat fixed little nitrogen. They were also efficient in partitioning nitrogen to the grain, as evidenced by the harvest index for nitrogen. It may be that this efficient partitioning of both carbohydrate and nitrogen resulted in an early diversion of photosynthate from the root system, particularly the nodules, so that nitrogen fixation was reduced.

A considerable amount of nitrogen ( 9 to $28 \mathrm{~kg}$ ha ') was lost as fallen plant parts (mostly leaves), with large differences between cultivars, but with a surprisingly similar and high percentage of nitrogen (mean $1.54 \%$, range from 1.23 to $1.68 \%$ ). The fallen plant parts represented 12 to $26 \%$ of the total $\mathbf{N}$ taken up by the plant. Assuming, with Sheldrake and Narayanan ${ }^{6}$, that we recover only $50 \%$ of the roots, then for cv BDN 1 , fallen plant parts and roots plus nodules potentially return $33 \mathrm{~kg} \mathrm{~N}$ ha to the soil, a figure very similar to the $40 \mathrm{~kg} \mathrm{~N}$ ha ${ }^{1}$ estimated by Sheldrake and Narayanan for ICP 1 , a variety with a similar maturity to BDN 1. The residual $\mathrm{N}$ ranged from $16 \mathrm{~kg} \mathrm{~N} \mathrm{a}^{-1}$ for the shortest-duration cultivars to $51 \mathrm{~kg} \mathrm{~N}$ for $\mathrm{T} 7$, the longest-duration cultivar, the amount correlating well with plant duration. This could account for the large residual effect of pigeonpea reported on a succeeding cereal crop".

Acknowledgement We thank $\operatorname{Dr} C$ Johansen for comments on the manuscript.

\section{References}

1 Derieux M 1971 Quelques donnees sur le comportement du pois d'angole on Guadoloupe (Antilles Francaises). Ann. de l'Ame. des plantes 21, 373-407.

2 Giller K E. Day J M. Dart P J and Wani S P 1984 A method for measuring the transfer of fixed nitrogen from free living bacteria to higher plants using ${ }^{\text {'s }} \mathbf{N}_{2}$. J. Microbiol. Methods 2 , 307-316.

3 International Crops Research Institute for the Serni-Arid Tropics 1978 ICRISAT Annual Report 1977-1978, Hyderabad. India, p. 100.

4 Kumar Rao J V D K and Dart P J 1979 Biology of nodulation of pigeonpea Cajanus cajan (L.) Millsp. In Proc. Sixth Aust. Legume Nodulation Conf., Perth, Australia, pp 80-82. 
5 Kumar Rao J V D K. Dan P J and Sastry P V S S 1983 Residual efiect of pigeonpea (Cajanus cajan) on yield and nitrogen response of maize. Expl. Agric. 19, 131-141.

6 Sheldrake A R and Narayanan A 1979 Growth, development and nutrient uptake in pigeonpeas (Cajanus cajan). J. Agric sci., Camb. 92, 513-526.

7 Sithanantham S. Kumar Rao J V D K, Reed W and Dart P J 1980 Studies on nodule damage in pigeonpea. In Proc. of the International Workshop on pigeonpeas, Vol. II, 15-19 Dec. 1980. ICRISAT, Patancheru, India, pp 409-415.

8 Sinha S K 1977 Food legumes: distribution, adaptability and biology of yield. FAO Plant Production and Protection Paper 3. Rome: FAO.

9 Thompson J A. Kumar Rao J V D K, Rupela O P, Giller K E and Day J M 1984 Contribution of nitrogen fixation by legumes in the semi-arid tropics. In Proc. of NifTAL conference on Nitrogen cycling in Cropping Systems involving Legumes, 13. 15 July 1983. Allentown, Pennsylvania. USA (in press). 